\title{
COMPARISON OF PRECIPITATION AND TEMPERATURE REGIME IN THE ŠUMAVA NATIONAL PARK AND IN THE SURROUNDING FOOTHILLS
}

\author{
KAROLÍNA BÍLÁ ${ }^{1, *}$, JIŘÍ HOSTÝNEK², and PAVEL KINDLMANN ${ }^{1,3}$ \\ ${ }^{1}$ Department of Biodiversity Research, Global Change Research Institute CAS, Bělidla 986/4a, 60300 Brno, Czech Republic \\ 2 Czech Hydrometeorological Institute, Mozartova 1237/41, 32300 Plzeň, Czech Republic \\ ${ }^{3}$ Institute of Environmental Studies, Charles University, Benátská 2, 12801 Prague 2, Czech Republic \\ * Corresponding author: kcerna@volny.cz
}

\section{ABSTRACT}

The IPCC IS92a scenario predicts climate changes including within-year fluctuations in precipitation and a temperature increase of $1.7^{\circ} \mathrm{C}$ by the year 2050 and a further $2.7^{\circ} \mathrm{C}$ by the year 2100 . We attempted to detect these changes in the Šumava Mts. and compare them with climate changes in the surrounding foothills. We used meteorological data records for the years 1961-2017, provided by the Czech Hydrometeorological Institute (CHMI). We recorded a decrease in precipitation, including snow cover, in the mountains and in the foothills during the last 15-20 years. Air temperature has also increased significantly in spring and summer over the last two decades. We assume that the increase in spring temperature negatively affects snow cover and causes it to melt earlier. We found that all these changes affect both the Šumava National Park and the surrounding foothills at the same rate; as a result, natural disturbances such as windstorm and bark beetle infestations occur more often and are more severe in both areas. Thus, changes in temperature and precipitation must be also considered in future management planning.

Keywords: climate change; foothills; forest management; mountains; rainfall; snow cover; Šumava

\section{Introduction}

Temperature is predicted by the IPCC IS92a scenario to increase by $1.7^{\circ} \mathrm{C}$ by the year 2050 and a further $2.7^{\circ} \mathrm{C}$ by the year 2100 (Mitchell 1995). Air warming is accompanied by a hydrological cycle with increases in precipitation and evaporation rates, which are slightly delayed after air temperature increases. Moreover, changes in precipitation are predicted with shifts in inter-annual variability, e.g. summer floods or less snow cover (Barry 1992). Inter-annual variability changes can also cause a decrease of soil moisture. However, this effect is regionally dependent on differences in soil structure (Boer et al. 2000).

Rainfall and runoff were intensively discussed in the Czech Republic, approximately from the beginning of the 21 st century, when this country experienced devastating floods. Besides climate warming, anthropogenic pressure also results in changes in landscape and weather and negative effects are monitored not only in lowlands but also in foothill areas and mountains (Kliment and Matoušková 2009). Many studies mention changes in land-cover as one of the consequences of human activity and changes in runoff and temperature, particularly on deforestation and afforestation (Hais and Pokorný 2004; Šantrůčková et al. 2010; Pokorný and Hesslerová 2011; Kindlmann et al. 2012; Bernsteinová et al. 2013; Bílá 2016).

In forested landscapes, an increase in temperature together with a decrease in precipitation can affect tree vitality or enhance insect population growth (Seidl et al. 2011) and thus cause trees to die (Hais and Kučera 2008; Bentz 2010; Bečka and Beudert 2016). There are insects spreading northwards, which may have a major effect on mature Norway spruce (Picea abies (L.) Karst.) forest in the Šumava Mts. Water fluxes (evapotranspiration or runoff) probably decrease as a result of a large forest dying (Beudert et al. 2007; Adams et al. 2012). This raises a question: are bark beetles (Ips typographus L.) responsible for changes in weather and water regimes?

Non-intervention areas in the Šumava National Park and subsequent proliferation of bark beetle there, especially during the period 2007-2012 (following the hurricane Kyrill), are often considered as causing a decrease in precipitation, increase in temperature and decrease of snow cover because of the intensive spruce tree dieback due to bark beetle. To test this, we determined whether there is a difference in the trends in precipitation, temperature and snow cover between the Šumava Mts. and adjacent foothills over the period 1961-2017.

\section{Methods}

\section{Study area}

The area studied is located on the Czech/German border. The Šumava National Park is situated on the Czech side and Bavarian forest National Park on the German side. The Czech Hydrometeorological Institute (CHMI) is responsible for maintaining meteorological stations and keeping records of meteorological data in the Czech Republic. We selected 9 meteorological stations in the Šumava NP: Horní Planá, Lenora, Borová Lada, Kvilda, Filipova Hut, Prášily, Churáňov, Železná Ruda and Špičák, and 7 in the adjacent foothills: Ktiš, České Budějovice, Husinec, Vlkonice, Temelín, Strakonice and Klatovy (Fig. 1). We have chosen the latter set 




Fig. 1 Locations of the meteorological stations in the Šumava Mts. (blue): Horní Planá, Lenora, Borová Lada, Kvilda, Filipova Hut', Prášily, Churáňov, Železná Ruda and Špičák, and in the adjacent foothills (red): Ktiš, České Budějovice, Husinec, Vlkonice, Temelín, Strakonice and Klatovy. Empty circles are other CHMI meteorological stations.

of meteorological stations in such a way that they uniformly covered a vast area adjacent to the Šumava NP, to exclude the possibility of neighbourhood effect on the analyses. We used meteorological data from all these stations for the years 1961-2017 with minor gaps, with particular emphasis on precipitation, snow cover and air temperature in order to identify yearly and seasonal changes and compare the climate in the mountains with that in the adjacent foothills.

\section{Data analyses}

Precipitation analyses are based on monthly mean values. We focused on the seasonal changes during the years 1961-2017. We also compared maximum snow cover and temperature fluctuations over the same period. All the data gaps were filled using the normal ratio method and data from nearby stations. Analyses were performed in MS Excel including XLSTAT (XLSTAT 2017). Fluctuations in the data were fitted by a polynomial function (precipitation and snow cover) or linear function (temperature) and the Mann-Kendall test and the Sen's slope estimates (Kendall 1975; Yue and Wang 2004) was used to determine the strength of the detected trends.

\section{Results}

The trends recorded in precipitation and temperature are shown in Figs. 2 and 4, based on the monthly mean values per season: winter (December, January, February), spring (March, April, May), summer (June, July, August) and autumn (September, October, November). A polynomial function was used to fit the fluctuations in precipitation and a linear trend line to fit the temperatures recorded from 1961-2017. Fig. 2 shows historical precipitation change in year 2000 thus we further focused on decrease in precipitation in years 2000-2017 and determined the strength of these trends using a Mann-Kendall test and the Sen's slope estimates (Fig. 3, Table 1). Fig. 4 shows a linear trend in temperature increase during the whole studied period 1961-2017 and the strength of these trends was also determined using a Mann-Kendall test and the Sen's slope estimates (Fig. 5, Table 2). Similarly, we tested the changes in maximum yearly snow cover from 1961-2017 (Fig. 6) and the trend strength from the evident historical change in year 2000, i.e. from years 2000-2017 (Fig. 7, Table 3). 

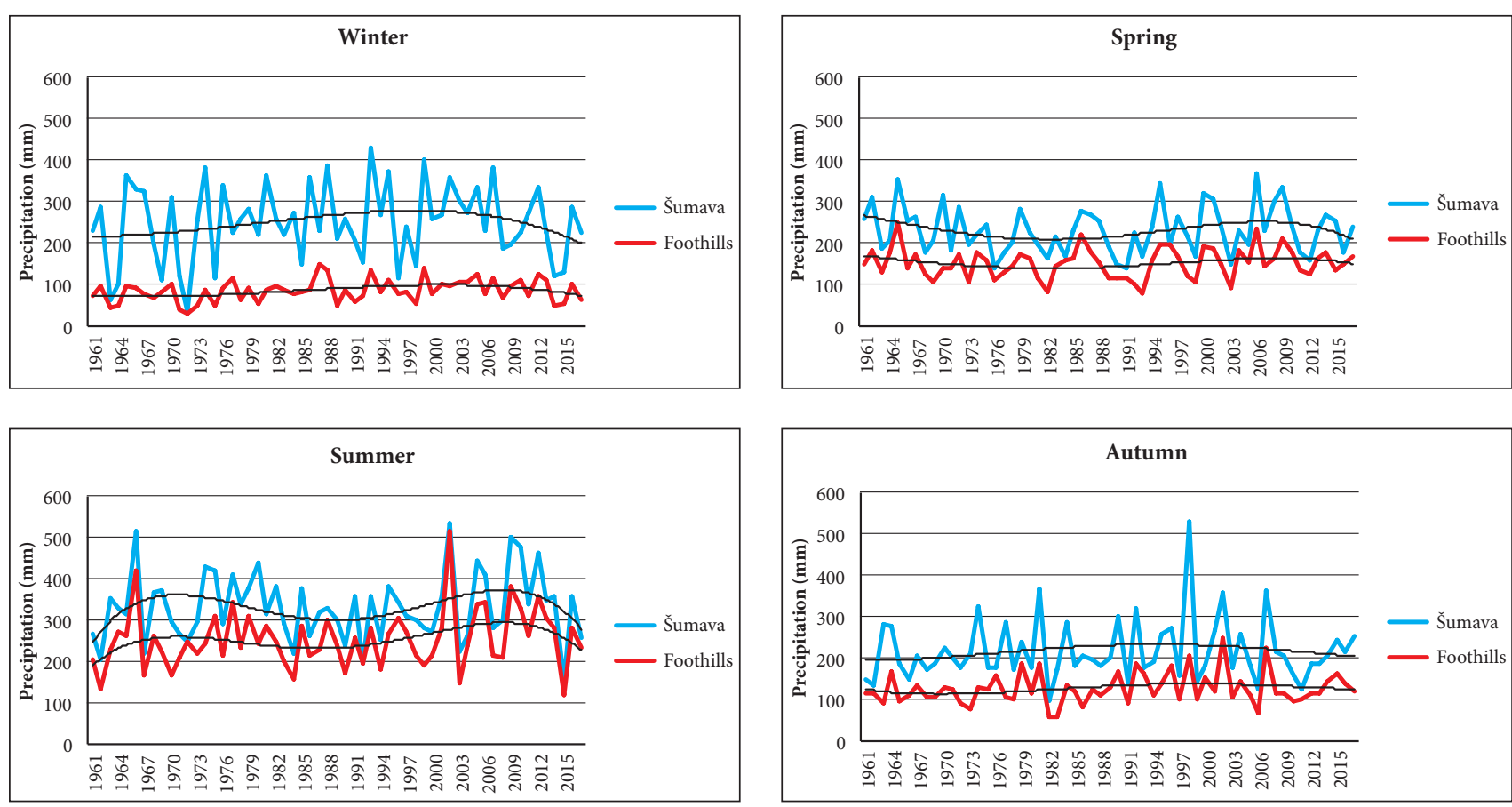

Fig. 2 Seasonal changes in precipitation recorded in the Šumava Mts. and surrounding foothills during the years 1961-2017 fitted by a polynomial function.
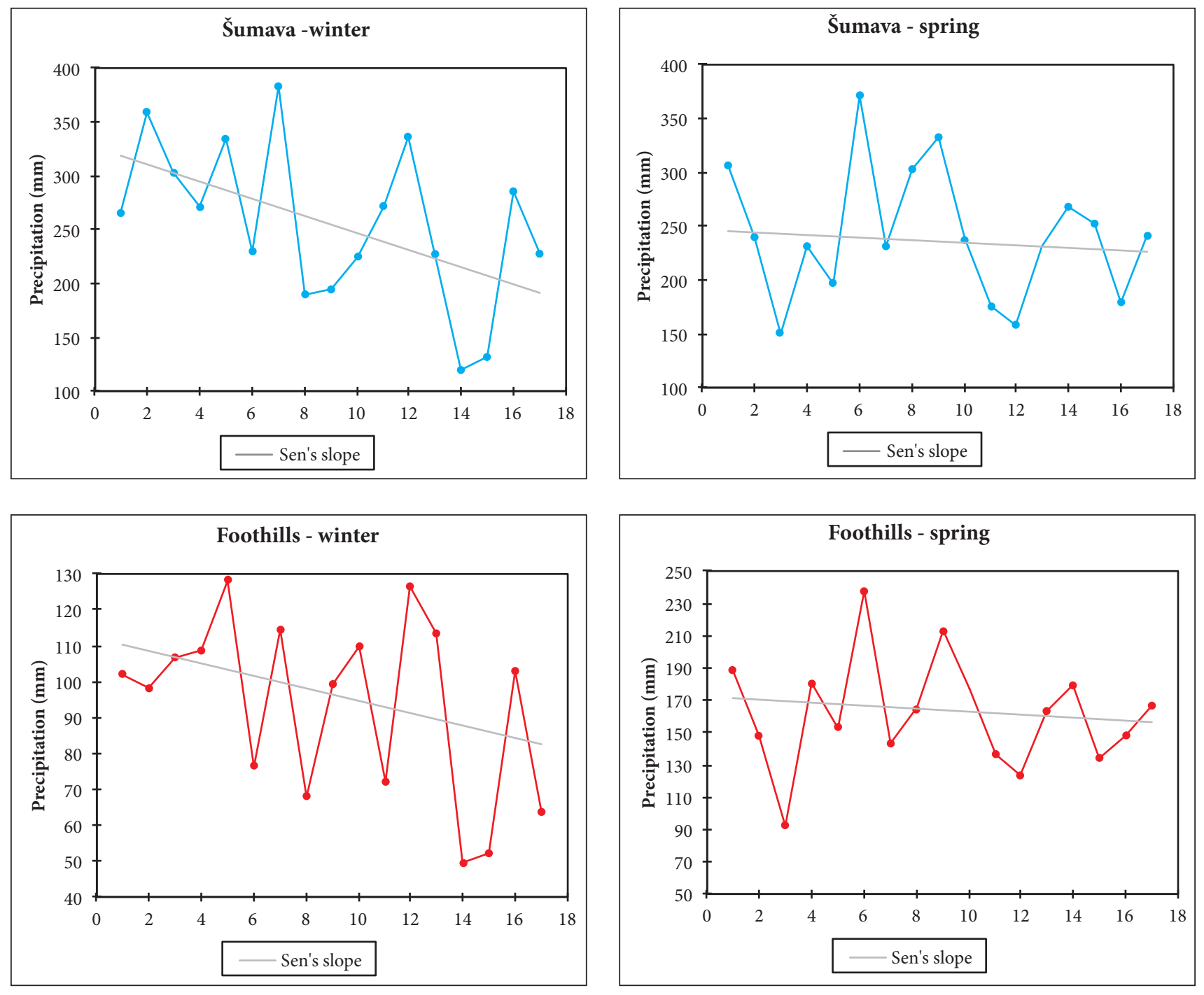

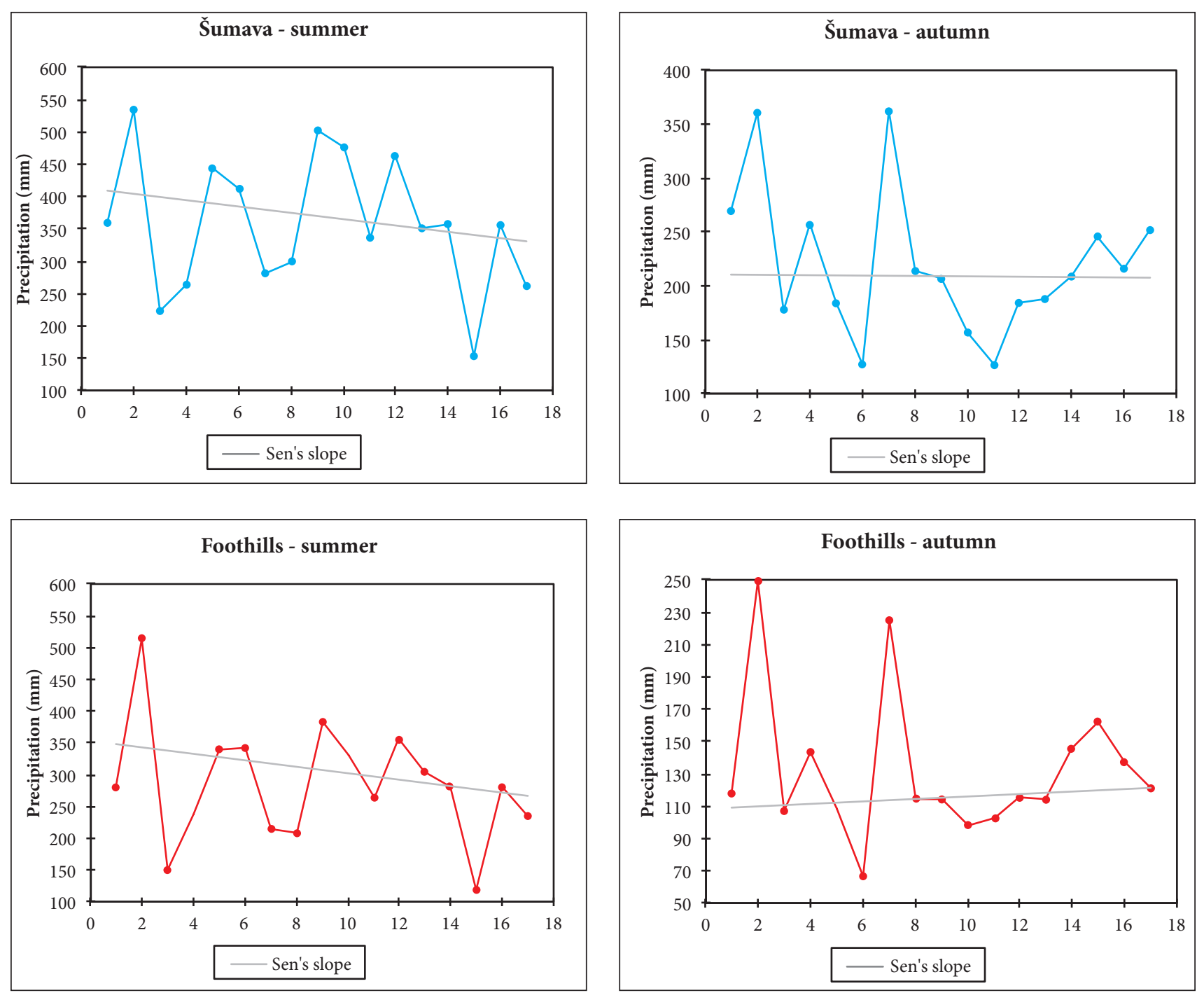

Fig. 3 Trends in precipitation recorded in the Šumava Mts. and surrounding foothills during the years 2000-2017 fitted by a linear function.

Table 1 Trends in precipitation recorded in the Šumava Mts. and surrounding foothills during the years 2000-2017 tested using a Mann-Kendall two-tailed test.

\begin{tabular}{|c|c|c|c|c|c|c|c|c|}
\hline \multirow{2}{*}{$\begin{array}{l}\text { Season } \\
\text { Locality }\end{array}$} & \multicolumn{2}{|c|}{ winter } & \multicolumn{2}{|c|}{ spring } & \multicolumn{2}{|c|}{ summer } & \multicolumn{2}{|c|}{ autumn } \\
\hline & Šumava & Foothills & Šumava & Foothills & Šumava & Foothills & Šumava & Foothills \\
\hline Kendall's tau & -0.265 & -0.191 & -0.088 & -0.118 & -0.118 & -0.118 & 0 & 0.103 \\
\hline$S$ & -36.0 & -26.0 & -12.0 & -16.0 & -16.0 & -16.0 & 0.0 & 14.0 \\
\hline $\operatorname{Var}(S)$ & 589.3 & 589.3 & 589.3 & 589.3 & 589.3 & 589.3 & 589.3 & 589.3 \\
\hline$p$-value & 0.149 & 0.303 & 0.650 & 0.537 & 0.537 & 0.537 & 1.000 & 0.592 \\
\hline alpha & 0.05 & 0.05 & 0.05 & 0.05 & 0.05 & 0.05 & 0.05 & 0.05 \\
\hline
\end{tabular}

There was a decline in precipitation starting in 2000, particularly during winter. However, no result was significant, including the winter decline recorded in the Sumava Mts.: $p$-value $=0.149$ on the foothills: $p$-value $=$ 0.303 . On the other hand, from 2000 onwards, temperature in winter (Šumava: $\mathrm{p}$-value $=0.025$, foothills: $\mathrm{p}$-value $=0.059)$, spring and summer increased significantly (p-values $<0.0001)$. There were also significant negative trends in snow cover from 2000 onwards (Šumava: $\mathrm{p}$-value $=0.029$, foothills: $\mathrm{p}$-value $=0.035$ )

\section{Discussion}

The trends of precipitation, including snow cover, show a decrease during the last 15-20 years. However, we also detected an increase in precipitation in spring and summer around the year 2000. These fluctuations and their inter-annual variability are clearly documented by the summer floods that affected the Czech Republic in 1997 and 2002. The changes in precipitation follow significant rises in temperature in spring and summer re- 

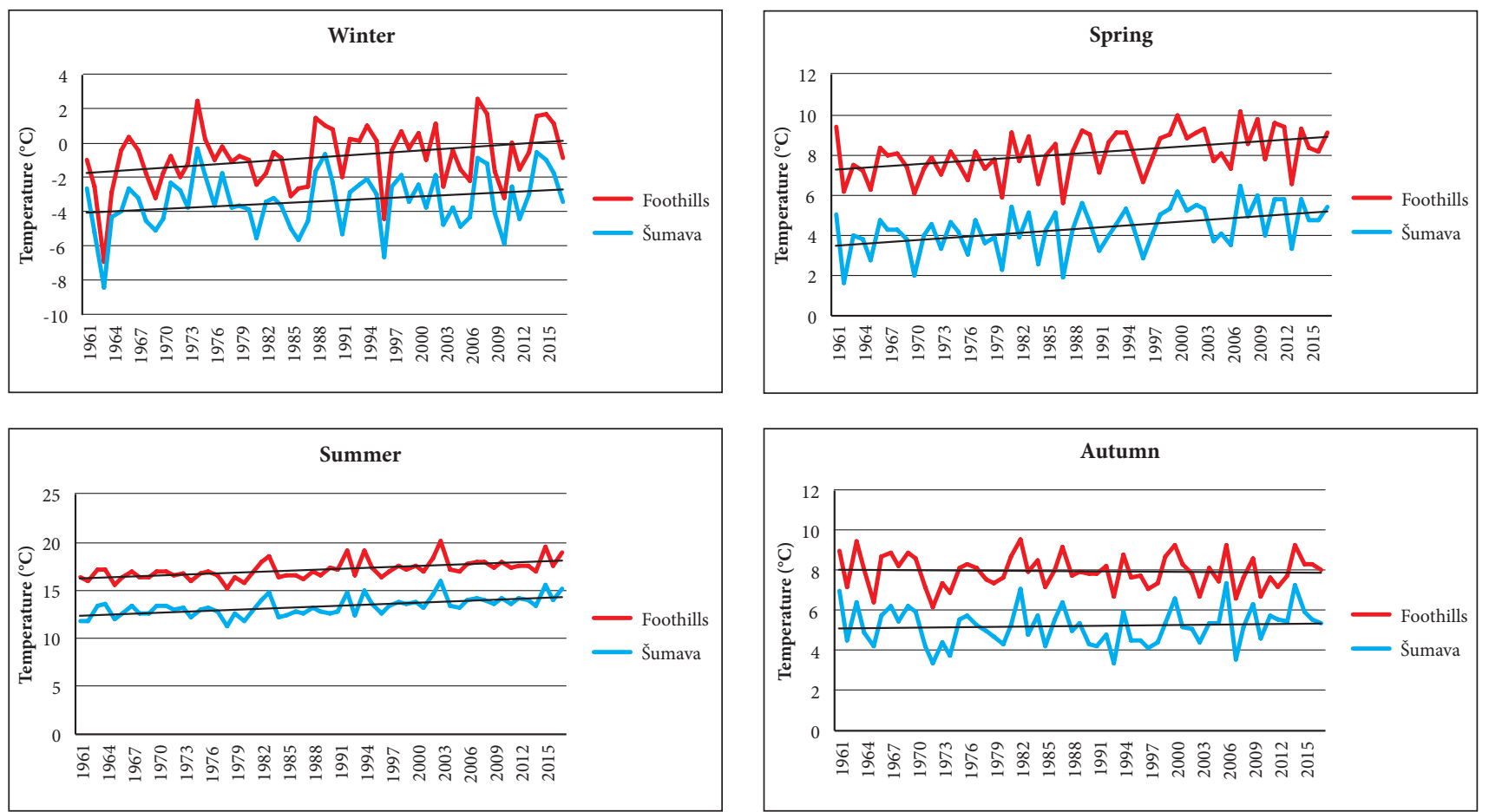

Fig. 4 Seasonal changes in temperature recorded in the Šumava Mts. and surrounding foothills during the years 1961-2017 fitted by a linear function.
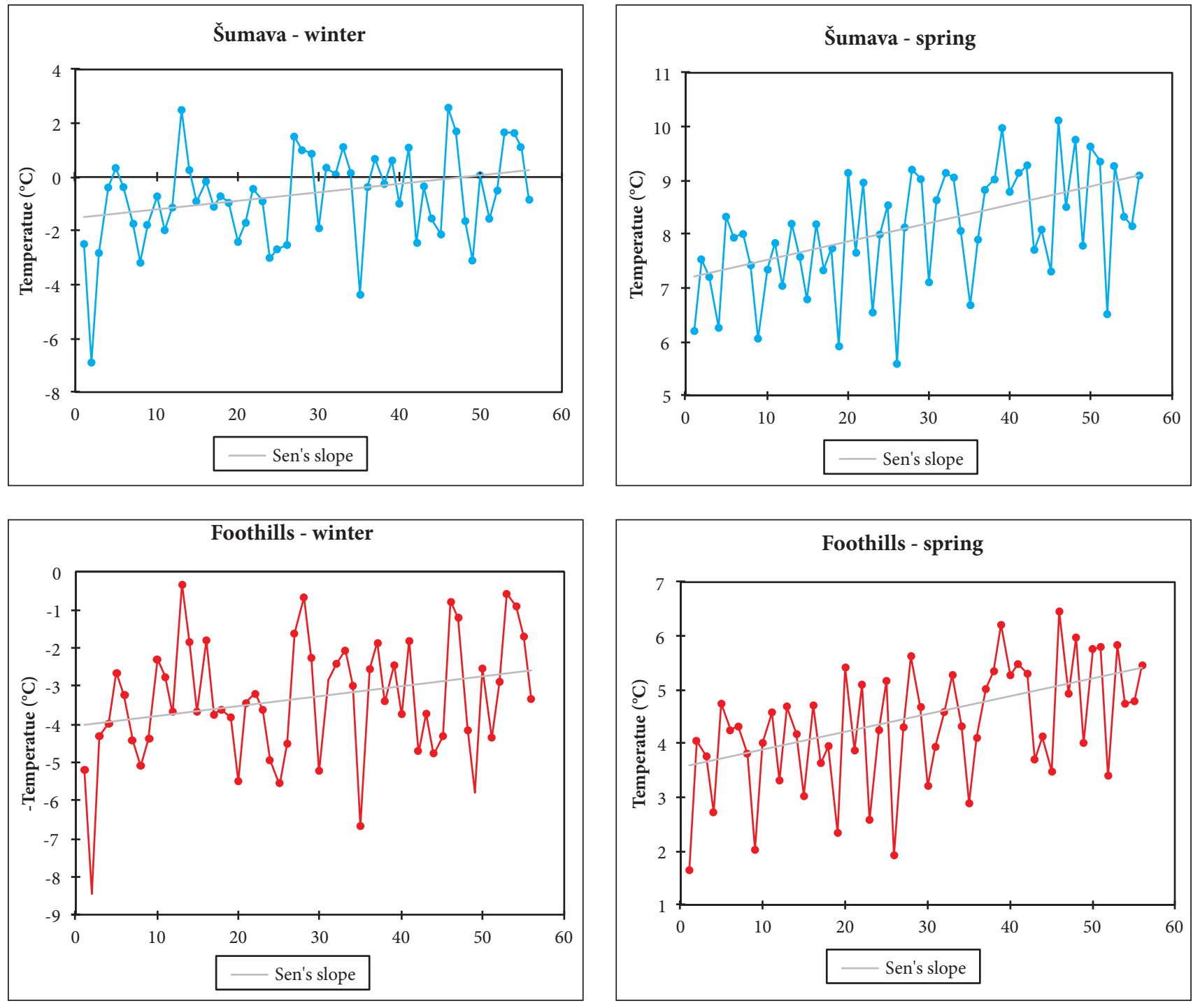

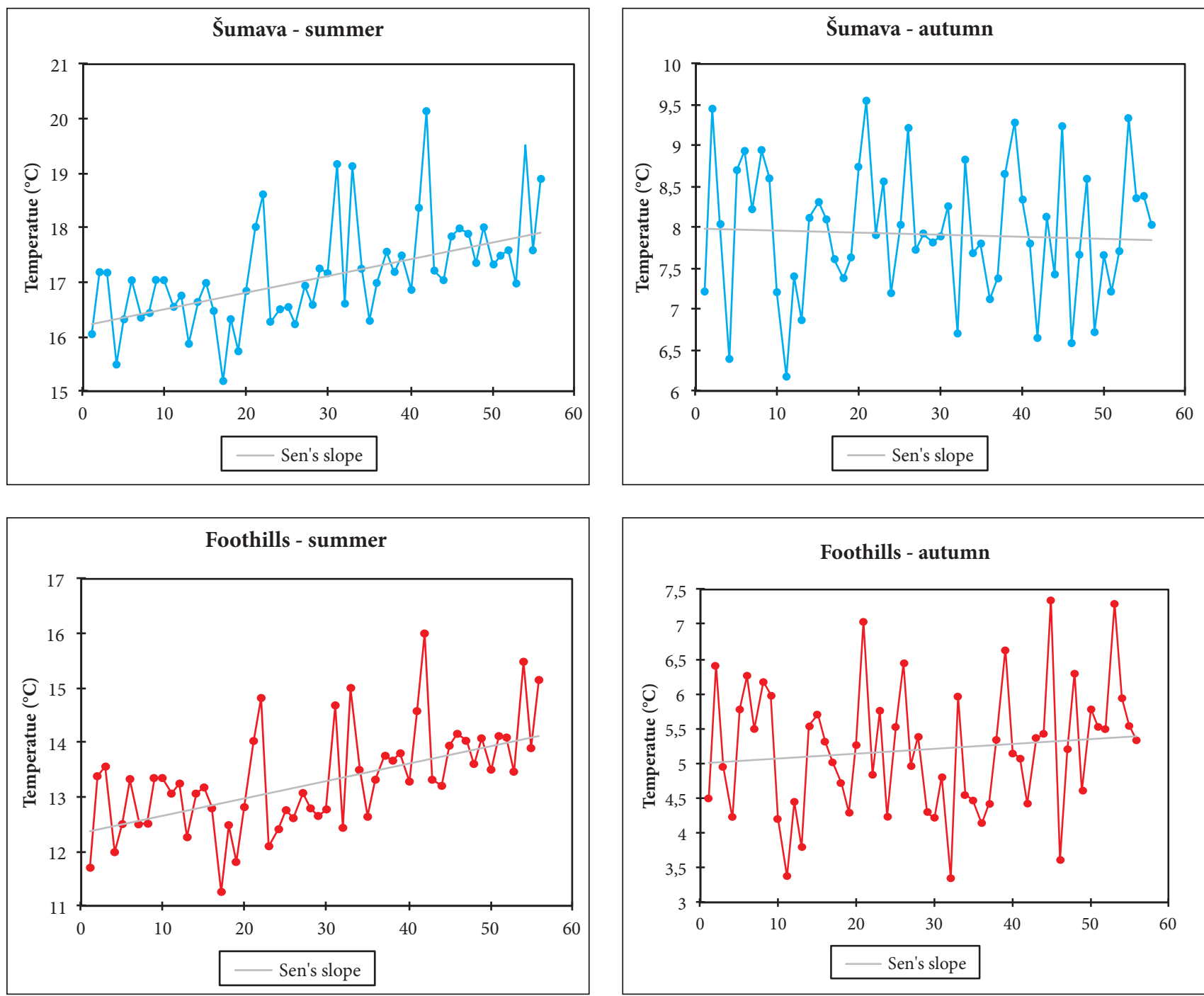

Fig. 5 Trends in temperature recorded in the Šumava Mts. and surrounding foothills during the years 1961-2017 fitted by a linear function.

Table 2 Trends in temperature recorded in the Šumava Mts. and adjacent foothills during the years 1961-2017 tested using a Mann-Kendall twotailed test.

\begin{tabular}{|l|c|c|c|c|c|c|c|c|}
\hline Season & \multicolumn{2}{|c|}{ winter } & \multicolumn{2}{c|}{ spring } & \multicolumn{2}{c|}{ summer } & \multicolumn{2}{c|}{ autumn } \\
\hline Locality & Šumava & Foothills & Šumava & Foothills & Šumava & Foothills & Šumava & Foothills \\
\hline Kendall's tau & 0.207 & 0.173 & 0.351 & 0.342 & 0.438 & 0.412 & -0.025 & 0.084 \\
\hline S & 318.0 & 267.0 & 540.0 & 526.0 & 675.0 & 634.0 & -39.0 & 130.0 \\
\hline $\operatorname{Var}(S)$ & 20018.0 & 20017.0 & 20020.0 & 20020.0 & 20019.0 & 20014.0 & 20019.0 & 20020.0 \\
\hline p-value & 0.025 & 0.059 & 0.000 & 0.000 & $<0.0001$ & $<0.0001$ & 0.783 & 0.358 \\
\hline alpha & 0.05 & 0.05 & 0.05 & 0.05 & 0.05 & 0.05 & 0.05 & 0.05 \\
\hline
\end{tabular}

corded over the last decades. This warming is also causing changes in snow cover and result in it melting earlier in the season. It is likely that total precipitation and snow cover were lower over approximately the last 20 years in the mountains and adjacent foothills.

However, our data do not support the hypothesis that there is a significant difference in the trends in precipitation, temperature or snow cover between the Šumava NP and adjacent foothills, neither over the period 1961-2017, nor over the period 2000-2017, as is clearly seen from the figures and Sen's slope values. Thus, the claims that the non-intervention areas in the Šumava National Park and subsequent proliferation of bark beetle there, especially during the period 2007-2012, following the hurricane Kyrill, are causing a decrease in precipitation, increase in temperature and decrease of snow cover because of the intensive spruce tree dieback due to bark beetle, are not supported by available meteorological data.

The changes in climate also altered hydrological processes in this area and affected forest stands on the summits of the mountains (Kliment and Matoušková 2009; Bernsteinová et al. 2015; Langhamer et al. 2015). These 


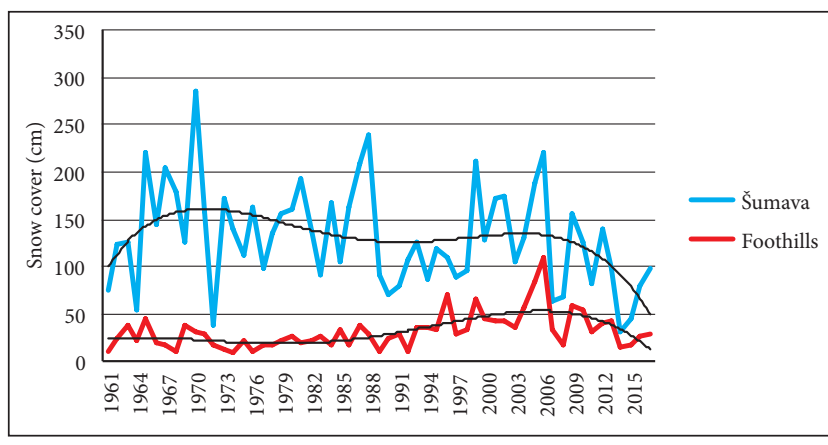

Fig. 6 Changes in snow cover (maximum snow cover/year) recorded in the Šumava Mts. and adjacent foothills during the years 1961-2017 fitted by a polynomial function.
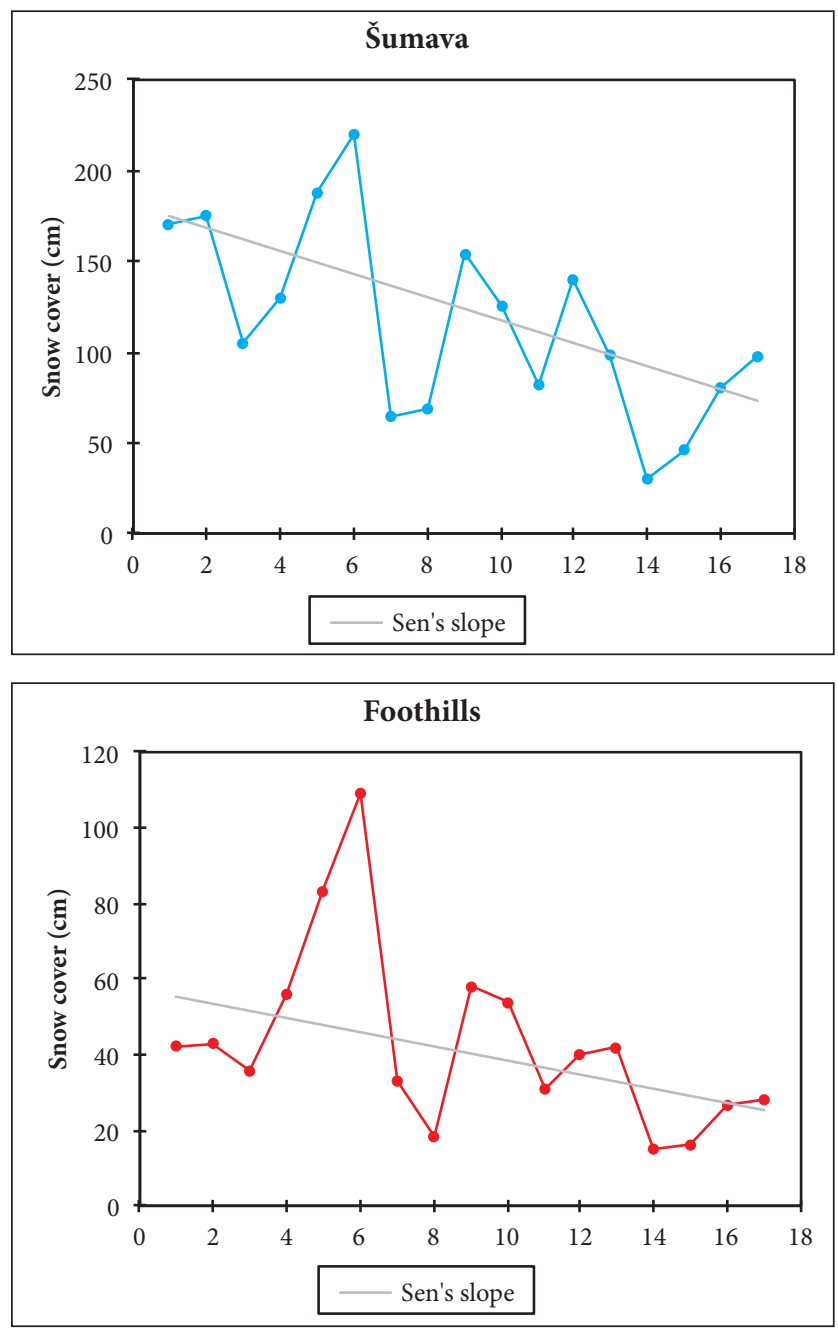

Fig. 7 Changes in snow cover (maximum snow cover/year) recorded in the Šumava Mts. and surrounding foothills during the years 2000-2017 fitted by a linear function.

Table 3 Trends in yearly snow cover recorded in the Šumava Mts. and surrounding foothills during the years 2000-2017 tested using a MannKendall two-tailed test.

\begin{tabular}{|l|c|c|}
\hline Locality & Šumava & Foothills \\
\hline Kendall's tau & -0.39115 & -0.376 \\
\hline $\mathrm{S}$ & -53.0 & -51.0 \\
\hline $\operatorname{Var}(\mathrm{S})$ & 588.3 & 588.3 \\
\hline p-value & 0.029 & 0.035 \\
\hline alpha & 0.05 & 0.05 \\
\hline
\end{tabular}

summits are covered with Norway spruce, which is very vulnerable to even slight droughts and devastating windstorms, which occurred in 1976, 1979, 1984, 1985, 1990, 2003, 2006, 2007 and 2008, followed by bark beetle attacks in the years 1945-1952, 1983-1988, 1992-1996, 2003-2010 and 2015- to now, which were closely monitored (Hošek 1981; Skuhravý 2002; Simanov 2014).

There have been long debates among scientists and politicians on how to protect natural forests and conserve valuable mountainous habitats and their biodiversity (Hais and Pokorný 2004; Jonášová and Prach 2004; Hojdová et al. 2005; Schwarz 2013; Bílá 2016). There are two main opinions: clear fell infected trees and remove them from the site or leave the dead forest on the site and leave it to spontaneously regrow. Making the right decision is not easy when large areas of forest are killed as the change quickly becomes obvious, within a few years. However, the type of forest needs to be distinguished before applying a specific type of forest management; either it is a forest planted for economic purposes or it is a natural forest within the national park, which is protected for its natural processes including regeneration after disturbance (Kindlmann and Křenová 2016). Although the change in climate is obvious and similar in both the Šumava NP and the surrounding foothills, spontaneous forest succession has already commenced in the vast area attacked by bark beetles (Bentz et al. 2010; Šantrůčková et al. 2010; Kindlmann et al. 2012; Økland 2015).

Climate changes are a common phenomenon in the Earth's history and people must learn how to react to them. During the past decades, weather monitoring techniques have improved greatly and we are able to predict future scenarios more precisely. The forecast is of increasing temperature and decreasing precipitation, which will significantly influence water supplies. It is advantageous to forecast these changes in time and carry out corresponding steps to adapt to such environmental changes.

\section{Acknowledgements}

This research was supported by the MSMT within the National Sustainability Program I (NPU I), grant number LO1415.

\section{REFERENCES}

Adams HD, Luce CH, Breshears DD, Allen CD, Weiler M, Hale VC et al. (2012) Ecohydrological consequences of droughtand infestation-triggered tree die-off: insights and hypotheses. Ecohydrology 5: 145-159.

Barry RG (1992) Mountain weather and climate, 2nd edn. Routledge, London, New York.

Bečka P, Beudert B (2016) Kůrovec a voda. Jak bezzásahovost ovlivňuje vodní režim na Šumavě. Šumava, jaro: 16-17. In Czech. In Czech. 
Bentz BJ, Régnière J, Fettig CJ, et al. (2010) Climate change and bark beetles of the western United States and Canada: direct and indirect effects. BioScience 60: 602-613.

Bernsteinová J, Bässler C, Zimmermann L, Langhammer J, Beudert $B$ (2015) Changes in runoff in two neighbouring catchments in the Bohemian Forest related to climate and land cover changes. J Hydrol Hydromech 63: 342-352.

Bílá K (2016) Are bark beetles responsible for drouhgts in the Šumava Mts.? Eur J Environ Sci 6: 108-113.

Beudert B, Klöcking B, Schwarze R (2007) Große Ohe. Impact of bark beetle infestation on the water and matter budget of a forested catchment. In: Puhlmann H, Schwarze R (eds) Forest hydrology - results of research in Germany and Russia. Deutsches Nationalkomitee für das International Hydrological Programme (IHP) der UNESCO und das Hydrology and Water Resources Programme (HWRP) der WMO. IHP/HWRP-Berichte Heft 6, Koblenz.

Boer G, Flato G, Ramsden D (2000) A transient climate change simulation with greenhouse gas and aerosol forcing: projected climate to the twenty-first century. Climate Dynamics 16: 427-450.

Hais M, Kučera T (2008) Surface temperature change of spruce forest as a result of bark beetle attack: Remote sensing and GIS approach. Eur J Forest Res 127: 327-336.

Hais M, Pokorný J (2004) Changes in land cover temperature and humidity parameters resulting from spruce forests decay. Aktuality šumavského výzkumu II: 49-55. In Czech.

Hojdová M, Hais M, Pokorný J (2005) Microclimate of a peat bog and of the forest in different states of damage in the National Park Šumava. Silva Gabreta 11: 13-24.

Hošek E (1981) Studie o výskytu kalamit na území ČSR od roku 1900: Brandýs nad Labem: Lesprojekt 10-12: 8-86. In Czech.

Jonášová M, Prach K (2004) Central-European mountain spruce forests: regeneration of tree species after a bark beetle outbreak. Ecol Eng 23: 15-27.

Kendall MG (1975) Rank correlation methods. Griffin, London.

Kindlmann P, Křenová Z (2016) Biodiversity: Protect Czech park from development. Nature 531: 448.
Kindlmann P, Matějka K, Doležal P (2012) Lesy Šumavy, lýkožrout a ochrana prírody. Karolinum, Praha. In Czech.

Kliment Z, Matoušková M (2009) Runoff Changes in the Šumava Mountains (Black Forest) and the Foothill Regions: Extent of Influence by Human Impact and Climate Change. Water Res Manag 23: 1813-1834.

Langhammer J, Su Y, Bernsteinová J (2015) Runoff Response to Climate Warming and Forest Disturbance in a Mid-Mountain Basin. Water 7: 3320-3342.

Mitchell JFB, Johns TC, Gregory JM, Tett SFB (1995) Climate response to increasing levels of greenhouse gases and sulphate aerosols. Nature 376: 501-504.

Økland B, Netherer S, Marini L (2015) The Eurasian spruce bark beetle: The role of climate. In: Björkman C, Niemelä P (eds) Climate Change and Insect Pests. CABI Climate Change Series, UK, pp 202-219.

Pokorný J, Hesslerová P (2011) Odlesňování a klima. Klimatické změny v Mau Forest v západní Keni. Vesmír 90: 573-578. In Czech.

Šantrůčková H, Vrba J et al. (2010) Co vyprávějí šumavské smrčiny: průvodce lesními ekosystémy Šumavy. Správa Národního parku a Chráněné krajinné oblasti Šumava. In Czech.

Schwarz J (2013) Clearing forest may transform local and global climate. Scientific American, March 4.

Seidl R, Schelhass MJ, Lexer MJ (2011) Unraveling the drivers of intensifying forest disturbance regimes in Europe. Global Change Biol 17: 2842-2852.

Simanov V (2014) Kalamity v historii a současnosti. Lesnická práce 93: 573-575. In Czech.

Skuhravý V (2002) Lýkožrout smrkový a jeho kalamity. Praha, Agrospoj. In Czech.

XLSTAT (2017) Data Analysis and Statistical Solution for Microsoft Excel. Addinsoft, Paris, France.

Yue S, Wang CY (2004) The Mann-Kendall test modified by effective sample size to detect trend in serially correlated hydrological series. Water Res Manag 18: 201-218. 